\title{
Article \\ Characteristics of Waste Generated in Dimension Stone Processing
}

\author{
Paweł Strzałkowski
}

Citation: Strzałkowski, P.

Characteristics of Waste Generated in Dimension Stone Processing. Energies 2021, 14, 7232. https://doi.org/ $10.3390 /$ en14217232

Academic Editors: Abdulnaser Sayma, Robert Król, Witold Kawalec, Izabela Sówka and Krzysztof M. Czajka

Received: 23 September 2021

Accepted: 26 October 2021

Published: 2 November 202

Publisher's Note: MDPI stays neutral with regard to jurisdictional claims in published maps and institutional affiliations.

Copyright: (C) 2021 by the author. Licensee MDPI, Basel, Switzerland. This article is an open access article distributed under the terms and conditions of the Creative Commons Attribution (CC BY) license (https:// creativecommons.org/licenses/by/ $4.0 /)$
Department of Mining, Faculty of Geoengineering, Mining and Geology, Wroclaw University of Science and Technology, Wybrzeże Wyspiańskiego 27, 50-370 Wrocław, Poland; pawel.strzalkowski@pwr.edu.pl

\begin{abstract}
Natural dimension stone processing generates large volumes of stone waste, which have a significant impact on the environment, as well as on the efficiency and profitability of the stoneprocessing plant. The article presents the characteristics of waste produced as a result of natural dimension stone processing and the structure of the waste production process. Solid stone scraps and sludge were distinguished. On the basis of the performed analyses, it was shown that stone waste constitutes $10-35 \%$ in relation to the quantity of the processed stone material, with the quantity of sludge being even threefold greater than the volume of solid scraps. According to the circular economy principles, the aim should be to reduce the amount of waste generated by reducing primary resources in favour of secondary material. Reducing the volume of stone waste is possible through rational planning of stone production while at the same time maximising the efficiency of stone material usage and introducing the most modern processing machines. This significant volume of stone waste encourages efforts to find solutions for both its management and reduction. This paper reviews the utility potential of stone waste. Sensible use of waste is important to increase the profitability and productivity of processing plants while incentivising environmental protection.
\end{abstract}

Keywords: stone waste; waste generation; waste recycling; industrial waste treatment; sustainable manufacturing; dimension natural stone processing

\section{Introduction}

Natural stone owes its popularity to its availability, performance, and decorative qualities. An accelerating trend towards the use of natural stone is also related to a wide variety of stones which may serve various purposes, for example, for use in window sills, work surfaces, cladding, or floor tiles. As a natural material, stone has unique physical and mechanical properties, and therefore, it is widely appreciated in construction. Some construction products made of natural stone and their parameters are standardised, e.g., in EN 1341 or EN 1469 [1]. The growing interest in natural stone entails increased production, which requires a number of processing machines and tools. It is important to select and use stone-processing machinery which would be adjusted to the manufacturing of particular natural stone products having defined properties and parameters of a final element.

Stones are processed with various devices, which give them proper shape and dimensions, as well as surface texture. Natural stone processing technology comprises a number of actions aimed at delivering stone products for various applications. However, apart from practical products, stone processing generates significant quantities of stone waste. This waste, as well as its efficient management, represents a great environmental problem in many countries [2-7]. The volume of generated stone waste largely depends on the amount of the processed material (and the efficiency of the processing plant), on the type and size of the generated waste, the type and geological properties of the stone, the type of machinery used for stone processing [4], as well as on the applied technology of dimension natural stone processing, the degree to which the block of stone is used in order to produce the final product and the needs of the clients. In order to identify its potential applications, 
it is important to identify the volume of stone waste generated, as well as its character [7]. However, this task is sometimes difficult, particularly when different types of natural stone are supplied to processing plants.

Issues related to stone waste have already been discussed in the literature $[2,4,7]$. However, these works discuss the problem from a general perspective or with specific examples and do not directly indicate to what extent the volume of generated stone waste depends on the technology used and type of waste. Meanwhile, it is important to know and understand the production processes of natural stone products, which, consequently, lead to the generation of different types of stone waste. Knowledge of the share of such waste in the total volume of processed stone material indicates the scale of the problem and the need to find a method of reusing it. This article characterises the process of generating stone wastes and indicates their types and quantities, as well as their potential application.

\section{Stone Wastes as a by-Product of Natural Dimension Stone Processing \\ 2.1. Definition of Stone Wastes}

Waste is generated in any company and should be understood as any substance or object which its owner disposes of, intends to dispose of, or is obliged to dispose of [8]. Depending on the specific nature of a company, the type and volume of waste differ. According to the European Parliament and European Commission Directive 2008/98/EC of 19 November 2008 on waste [8], each economic entity is obliged to have an adequate waste management policy. Economic activity should result in a possibly limited waste generation. If this is impossible, waste should be recovered, then recycled, or if no other option is available, stored in dedicated sites. Stone wastes that are recovered and reused should be understood as scraps.

Mining wastes are a characteristic type of waste. They comprise by-products generated during the exploration and mining stages, as well as in physical and chemical processing and treatment of minerals. Careddu [2], Kaźmierczak et al. [5,9], Yurdakul [7], TayebiKhorami et al. [10], and Woźniak and Pactwa [11] note that these wastes pose significant problems despite their vast potential for further use. Moreover, they seem impossible to be completely eliminated. Therefore, it is important to explore different solutions to reduce and manage them [12]. A reduction in waste is possible by following the circular economy rule, which promotes a drastic reduction in primary resources in favour of secondary material flowing through internal cycles. Lèbre et al. [13] emphasise that it is unreasonable to believe that mining is becoming an unnecessary economic sector. The growing demand for mineral resources will continue to render mining processes indispensable. However, proper management of Earth's resources and adoption of the circular economy rule is the basis for reducing the amount of waste generated in mineral mining and processing.

Stone wastes generated as a result of natural stone processing in stonemasonry companies represent a special type of mining waste. Stone wastes are typically large and medium-size fragments, as well as small parts of stone produced in stone processing, or ready stone products which do not meet the quality standards. According to the European Commission Decision of 18 December 2014 amending Decision 2000/532/EC on waste registers in accordance with European Parliament and EC Directive 2008/98/EC [14], wastes generated in natural stone processing are classified as wastes from stone cutting and sawing (code 0104 13). Importantly, these wastes are not classified as dangerous wastes.

The waste from natural dimension stone processing becomes a serious problem because the amount of waste generated reaches enormous volumes, which makes it practically impossible to neutralise this waste properly [15]. Additionally, the stone processing technologies and types of stone products make it difficult to limit the volume of waste produced in stonemasonry companies. Production may be more effective and economic and may result in a smaller quantity of waste, if some part of the waste is reused into other stone products or if stones are processed with the use of innovative technologies. However, the most significant reductions in natural stone wastes may be achieved through proper organisation of the processing plants and increased awareness of the management staff [6]. 
Mitchell et al. [16] and Shamrai et al. [17] observe numerous benefits of rational stone waste management, the most significant of which are the potential revenue from the sale of stone waste, thus becoming an additional income for the company, and also a rational use of natural resources. The benefits also include a decreased amount of material lost in extraction and processing, lower costs of waste storage, transportation, and disposal, as well as increased social responsibility of the company.

\subsection{Structure of Stone Waste Production in Processing Plants}

Stonemasonry companies process natural stone supplied in the form of raw blocks or pre-processed elements requiring further treatment. The fundamental stage in producing a stone element is its processing, which consists of cutting, milling, or providing the desired texture to its surface. Usually, various types of stone (e.g., granite, sandstone, marble, limestone, etc.) are processed in stonemasonry companies, and various stone products are manufactured. Much less often, stonemasonry companies specialise in the manufacturing of one product (serial production) or in processing one type of natural stone. Stonemasonry companies that process one type of stone most often are plants located near mines extracting this particular stone type.

Except for the finished stone product, the processing of natural dimension stone results in solid scraps (Figure 1a) and sludge (Figure 1b). Depending on the particular process, technology involved and type of natural stone (e.g., granite, sandstone), the size and type of waste are different (Figure 2).

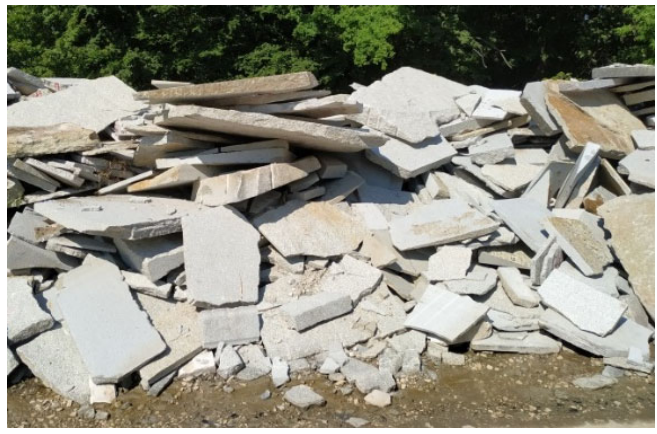

(a)

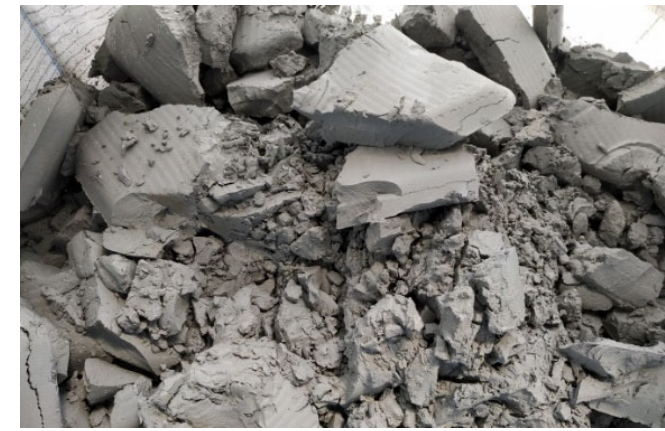

(b)

Figure 1. Stone waste: (a) crushed slabs (different waste size); (b) sludge.

Solid scraps are produced in the process of cutting off larger parts of natural stone or giving the texture of stone surfaces without the use of water. Solid scraps have various sizes, from a few millimetres to several hundred centimetres [4]. The most common type of solid scrap includes offcuts, i.e., rough-edged stone cut off the stone block in order to achieve regular surfaces of the stone block (Figure 3). The length and width of the offcuts are usually equal to the size of the stone block being worked on (e.g., $2.5 \times 1.5 \mathrm{~m}$ ). However, the thickness of this waste is from several to several dozen $\mathrm{cm}$. It should be noted that the sizes of these scraps depend on the quality of the processed stone block (regular and equal shape of the stone block), which is influenced by the adopted mining technology. Therefore, a properly selected dimension stone mining technology may significantly reduce the size of the produced stone waste. 


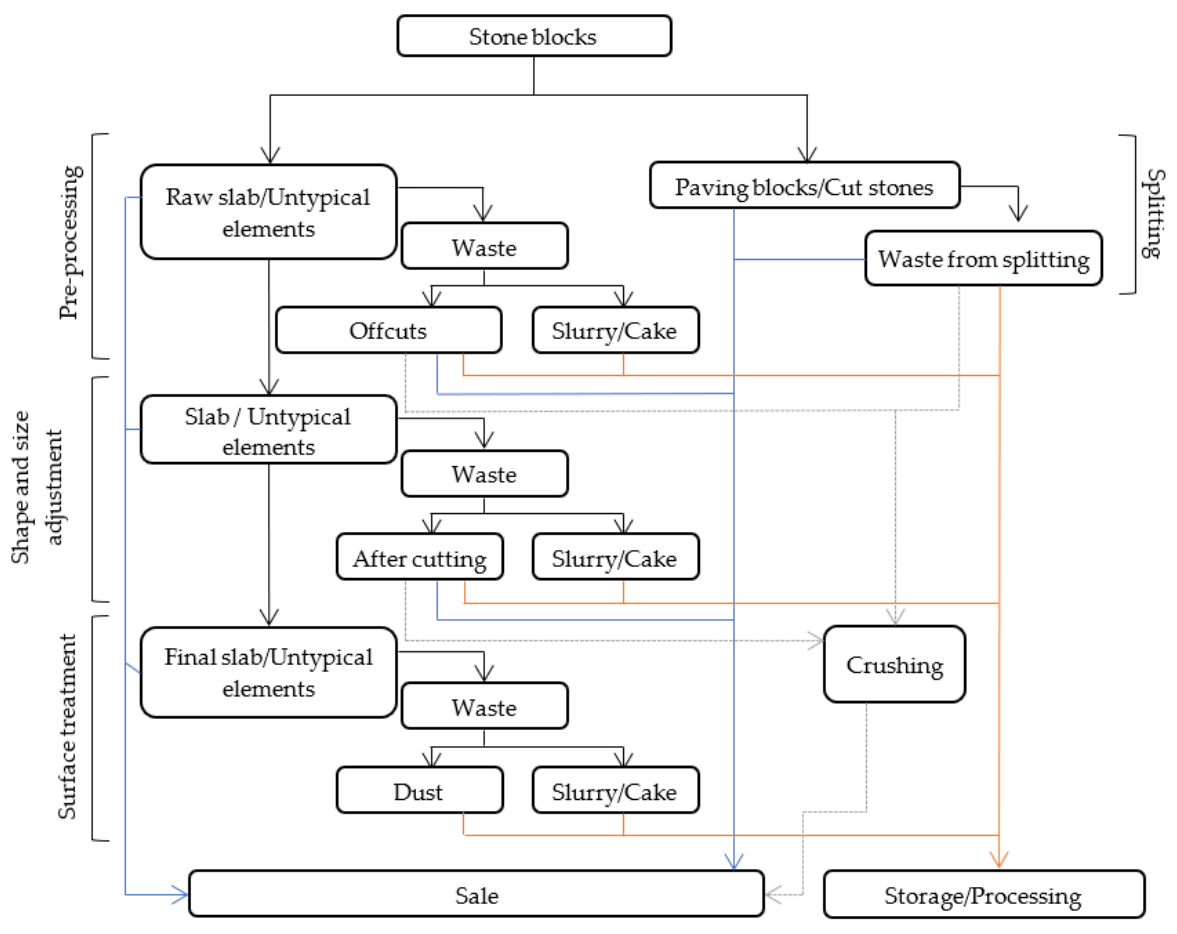

Figure 2. General diagram representing waste production in the processing of natural stone.

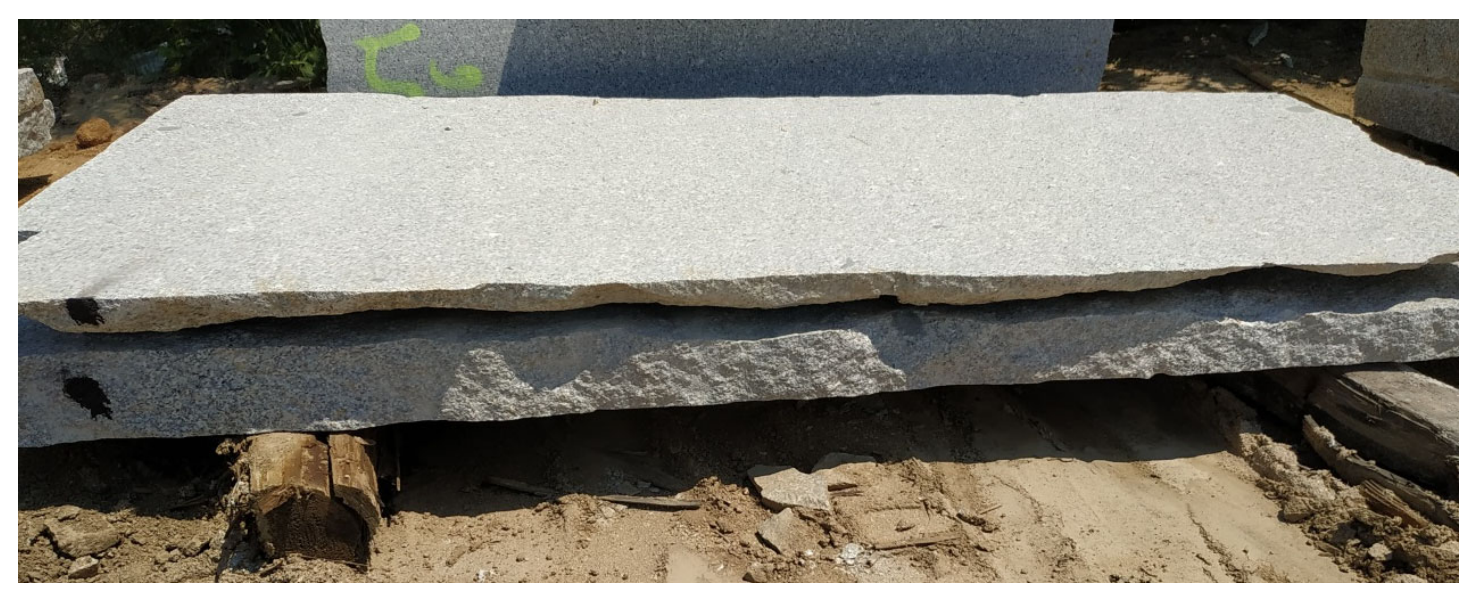

Figure 3. Offcuts (2.5 $\mathrm{m}$ long, $1.5 \mathrm{~m}$ wide, $0-0.1 \mathrm{~m}$ thick).

Depending on the pre-processing technology employed, a valvestone can be formed in this process. Valvestone is the lower part of the cut stone block that remains in the block cutting machines for safety reasons. The size of this type of scrap is similar to the size of the offcuts.

Other scraps include stone fragments cut or split (in the process of giving the stone element its desired size and shape, and when split stone elements are produced) or dust, generated as a result of texturising the stone by an impact action (e.g., pointing, chiselling) or by flame treatment. The dimensions of scraps produced after cutting or splitting are from several to several dozen centimetres, while dust waste is usually up to $1 \mathrm{~mm}$.

Stone sludge is produced by using water as a medium for cooling and removing fine stone particles from underneath the processing tool. They are a mixture of ground rock mass with water and may additionally contain some small quantities of abrasive material (particles of the synthetic diamond). The majority of grains in sludge are smaller than $100 \mu \mathrm{m}$ and rarely larger than $150 \mu \mathrm{m}$ [4]. Importantly, stone sludge represents the greatest volume of processing-related wastes. While the volume of solid scraps may be reduced by 
rational stone material handling, a reduction in the volume of sludge is difficult without alternating the employed stone-processing technology.

The above-mentioned wastes are accompanied by wastes from damaged stone blocks or final stone products. These include materials with inherent defects (fractures, voids, etc.) and secondary defects (e.g., defects resulting from the manufacturing process). Such materials are frequently reprocessed or sold at discount prices. Table 1 contains a detailed characteristic of wastes generated in the processing of natural stone.

Table 1. Characteristics of waste from the processing of natural stone.

\begin{tabular}{cc}
\hline Type of Waste & Definition of Waste \\
\hline Damaged stone blocks & $\begin{array}{c}\text { Stone blocks that have significant defects } \\
\text { or have been damaged and are } \\
\text { characterised by different sizes and } \\
\text { irregular shapes. }\end{array}$ \\
\hline Damaged final stone products & $\begin{array}{c}\text { Final stone products with inherent and } \\
\text { secondary defects. }\end{array}$ \\
\hline
\end{tabular}

Offcuts

The first and last slab of a stone block cut in a head saw, having one surface smooth and one surface raw/split.
Stone blocks that have insufficient material quality or have been damaged during transport or unsuccessfully divided into smaller parts.

During the processing operation, fractures or defects in the final stone products may occur (secondary defects) or primary defects are revealed.

Offcuts occur when a stone block with uneven surfaces is cut. The basic operation behind cutting a stone block is to approximate its shape to a cube. Offcuts are due to the technology employed in natural stone processing.

Waste is generated after cutting a stone block due to safety reasons and in order not to damage the cut raw slabs. This waste is generated as a result of using certain stone block cutting technologies (e.g., disc saw) and is less and less frequent.

Valvestones Lower part of the cut stone block

When splitting natural stone into smaller-size elements (e.g., in the production of paving stone), oversize rock parts of the desired element are split off.

Waste is produced as part of the size and shape adjustment. Rock material is produced as a result of cutting off the oversize parts of natural stone. The quantity of this waste depends on the volume of the cutoff stone parts and on the planned cutting locations.

As stone is processed, fine fractions of rock material and spalls are split/chipped off the rock. In addition,

Dust Fine fraction rock and abrasive material. depending on the surface treatment technology used, this type of waste may include abrasive material

(e.g., sand being the product of sandblasting).

\section{STONE SLUDGE}

Slurry/Cake
A mixture of water, ground fine rock, and particles of the cutting tool.
This type of waste is generated at each stage of stone processing. Stone is abraded by the processing elements and subsequently mixed with water. This type of waste additionally comprises small amounts of particles from the working tools. 


\subsection{Analysis of Stone Waste Production}

Analysing the volume and type of the produced stone materials is an important parameter in selecting proper machinery for a processing plant, as well as the basis for the adoption of a production management strategy with a view to reducing the volume of waste produced. The machinery is selected on the basis of numerous other factors, the most important of which is the type of stone products. Table 2 shows types of processed natural stone, types of stone products, and machinery used in 10 plants in which the scale and type of processing-related stone waste were analysed. The plants process various types of rocks (granites, sandstones, marbles, etc.) and produce various elements (stone slabs, paving blocks, untypical and formed elements, etc.).

The volumes of natural stone waste produced in stonemasonry companies vary. Table 3 shows the analysis of the volume and type of stone wastes (scraps). The volume of stone wastes (scraps) was analysed based on data obtained from processing plants on the flow of semi-finished products in the individual stages of stone processing, as well as on the author's own observations. The volume of stone wastes generated at individual stages was estimated from the differences in the volume of stone elements before and after the processing stage. The same basis was used to identify the masses of processed stone and semi-finished products. The volume and mass of sludge were determined from measurements (weighing) conducted by the processing plants. The volume of solid stone scraps was calculated from the difference in initial weight and volume of processed dimension natural stone, finished stone products, and sludge.

The analyses demonstrated that the volumes of stone wastes (scraps) are between $10 \%$ and $35 \%$ in relation to the quantity of the processed stone material. Interestingly, the greatest volume of waste is produced at the pre-processing stage. This phenomenon is related to the greatest amount of work involved and to the amount of processed natural stone, as well as to the type of machinery employed. In the complete stone processing cycle, the volume of sludge is in all analysed plants more than the volume of solid wastes (solid scraps) (up to three times more). Solid wastes (solid scraps) are generated in the pre-processing and, to a lower extent, in the shape and size adjustment processes. They are characterised by larger fragments of natural stone, which can be processed again, thus significantly reducing the volume of stone waste produced. Stone sludge is a much more significant problem because it is a fine material and cannot be reprocessed. Therefore, it is necessary to use it in other industrial sectors. 
Table 2. Types of stone products and machinery used in plants in which the scale and type of stone waste were analysed.

\begin{tabular}{|c|c|c|c|c|c|c|c|c|c|c|}
\hline & $\begin{array}{l}\text { Processing } \\
\text { Plant } 1\end{array}$ & $\begin{array}{l}\text { Processing } \\
\text { Plant } 2\end{array}$ & $\begin{array}{l}\text { Processing } \\
\text { Plant } 3\end{array}$ & $\begin{array}{l}\text { Processing } \\
\text { Plant } 4\end{array}$ & $\begin{array}{l}\text { Processing } \\
\text { Plant } 5\end{array}$ & $\begin{array}{l}\text { Processing } \\
\text { Plant } 6\end{array}$ & $\begin{array}{l}\text { Processing } \\
\text { Plant } 7\end{array}$ & $\begin{array}{l}\text { Processing } \\
\text { Plant } 8\end{array}$ & $\begin{array}{l}\text { Processing } \\
\text { Plant } 9\end{array}$ & $\begin{array}{l}\text { Processing } \\
\text { Plant } 10\end{array}$ \\
\hline $\begin{array}{c}\text { Type of } \\
\text { natural stone }\end{array}$ & $\begin{array}{l}\text { granite, } \\
\text { limestone, } \\
\text { marble }\end{array}$ & $\begin{array}{l}\text { granite, } \\
\text { marble }\end{array}$ & $\begin{array}{c}\text { granite, } \\
\text { sandstone }\end{array}$ & $\begin{array}{c}\text { granite, gneiss, } \\
\text { marble, } \\
\text { sandstone, } \\
\text { limestone, } \\
\text { onyx }\end{array}$ & sandstone & granite & $\begin{array}{l}\text { sandstone, } \\
\text { limestone, } \\
\text { marble }\end{array}$ & $\begin{array}{l}\text { granite, } \\
\text { sandstone, } \\
\text { limestone, } \\
\text { marble }\end{array}$ & sandstone & $\begin{array}{l}\text { granite, } \\
\text { sandstone }\end{array}$ \\
\hline Production & $\begin{array}{l}\text { cladding slabs, } \\
\text { stairs, window } \\
\text { sills, paving } \\
\text { blocks }\end{array}$ & $\begin{array}{l}\text { raw slabs } \\
\text { stairs, window } \\
\text { sills, paving } \\
\text { blocks, curbs }\end{array}$ & $\begin{array}{l}\text { cladding slabs, } \\
\text { stairs, window } \\
\text { sills, curbs }\end{array}$ & raw slabs & $\begin{array}{c}\text { raw slabs, } \\
\text { cladding slabs, } \\
\text { formed } \\
\text { elements, } \\
\text { untypical } \\
\text { elements }\end{array}$ & $\begin{array}{c}\text { raw slabs, } \\
\text { paving blocks, } \\
\text { curbs }\end{array}$ & $\begin{array}{l}\text { raw slabs, } \\
\text { cladding slabs, } \\
\text { stairs, window } \\
\text { sills, formed } \\
\text { elements }\end{array}$ & $\begin{array}{l}\text { raw slabs, } \\
\text { cladding slabs, } \\
\text { stairs, window } \\
\text { sills, formed } \\
\text { elements, } \\
\text { curbs }\end{array}$ & $\begin{array}{l}\text { raw slabs, } \\
\text { cladding slabs, } \\
\text { formed } \\
\text { elements }\end{array}$ & raw slabs \\
\hline $\begin{array}{c}\text { Pre- } \\
\text { processing }\end{array}$ & $\begin{array}{c}\text { gang saw, disc } \\
\text { saw, } \\
\text { multi-wire } \\
\text { diamond saw }\end{array}$ & $\begin{array}{c}\text { gang saw, disc } \\
\text { saw }\end{array}$ & gang saw & $\begin{array}{l}\text { multi-wire } \\
\text { diamond saw }\end{array}$ & gang saw & $\begin{array}{c}\text { gang saw, } \\
\text { multi-wire } \\
\text { diamond saw, } \\
\text { stone splitting } \\
\text { machine }\end{array}$ & $\begin{array}{c}\text { gang saw, } \\
\text { multi-wire } \\
\text { diamond saw }\end{array}$ & $\begin{array}{c}\text { gang saw, } \\
\text { multi-wire } \\
\text { diamond saw }\end{array}$ & $\begin{array}{c}\text { multi-wire } \\
\text { diamond saw }\end{array}$ & gang saw \\
\hline $\begin{array}{c}\text { Shape and size } \\
\text { adjustment }\end{array}$ & table saw & table saw & table saw & - & table saw & - & table saw & table saw & table saw & - \\
\hline $\begin{array}{l}\text { Surface } \\
\text { treatment }\end{array}$ & $\begin{array}{l}\text { abrasive- } \\
\text { polishing line, } \\
\text { side grinder, } \\
\text { thermal } \\
\text { burner, } \\
\text { graining } \\
\text { machine, } \\
\text { sandblaster }\end{array}$ & $\begin{array}{l}\text { abrasive- } \\
\text { polishing line, } \\
\text { side grinder, } \\
\text { thermal } \\
\text { burner }\end{array}$ & $\begin{array}{l}\text { abrasive- } \\
\text { polishing line, } \\
\text { side grinder, } \\
\text { graining } \\
\text { machine, } \\
\text { sandblaster }\end{array}$ & $\begin{array}{l}\text { abrasive- } \\
\text { polishing line, } \\
\text { thermal } \\
\text { burner }\end{array}$ & $\begin{array}{l}\text { abrasive- } \\
\text { polishing } \\
\text { line }\end{array}$ & - & $\begin{array}{l}\text { abrasive- } \\
\text { polishing } \\
\text { line }\end{array}$ & $\begin{array}{l}\text { abrasive- } \\
\text { polishing line, } \\
\text { graining } \\
\text { machine }\end{array}$ & $\begin{array}{l}\text { abrasive- } \\
\text { polishing } \\
\text { line }\end{array}$ & $\begin{array}{c}\text { abrasive- } \\
\text { polishing line, } \\
\text { sandblaster }\end{array}$ \\
\hline
\end{tabular}


Table 3. Average volume of stone waste produced per month in each of the processing stages.

\begin{tabular}{|c|c|c|c|c|c|c|c|c|c|c|c|c|c|c|c|c|}
\hline & & \multicolumn{3}{|c|}{ Processing Plant 1} & \multicolumn{3}{|c|}{ Processing Plant 2} & \multicolumn{3}{|c|}{ Processing Plant 3} & \multicolumn{3}{|c|}{ Processing Plant 4} & \multicolumn{3}{|c|}{ Processing Plant 5} \\
\hline \multicolumn{2}{|c|}{$\begin{array}{l}\text { Quantity of rock material to be } \\
\text { processed, } \mathrm{m}^{3}\end{array}$} & \multicolumn{3}{|c|}{268.00} & \multicolumn{3}{|c|}{244.88} & \multicolumn{3}{|c|}{175.25} & \multicolumn{3}{|c|}{291.67} & \multicolumn{3}{|c|}{179.79} \\
\hline & & \multicolumn{2}{|c|}{$\begin{array}{l}\text { Quantity of stone } \\
\text { waste }\end{array}$} & $\begin{array}{c}\text { Loss of } \\
\text { stone } \\
\text { material } \\
\% \\
8.34\end{array}$ & \multicolumn{2}{|c|}{$\begin{array}{l}\text { Quantity of stone } \\
\text { waste }\end{array}$} & $\begin{array}{c}\text { Loss of } \\
\text { stone } \\
\text { material } \\
\% \\
7.82\end{array}$ & \multicolumn{2}{|c|}{$\begin{array}{l}\text { Quantity of stone } \\
\text { waste }\end{array}$} & $\begin{array}{c}\text { Loss of } \\
\text { stone } \\
\text { material } \\
\% \\
21.98\end{array}$ & \multicolumn{2}{|c|}{$\begin{array}{l}\text { Quantity of stone } \\
\text { waste }\end{array}$} & $\begin{array}{c}\text { Loss of } \\
\text { stone } \\
\text { material } \\
\% \\
14.40\end{array}$ & \multicolumn{2}{|c|}{$\begin{array}{l}\text { Quantity of stone } \\
\text { waste }\end{array}$} & $\begin{array}{c}\text { Loss of } \\
\text { stone } \\
\text { material } \\
\% \\
4.76\end{array}$ \\
\hline processing & $\begin{array}{l}\text { Solid stone } \\
\text { scraps }\end{array}$ & 8.45 & 82.30 & 3.15 & 8.76 & 71.18 & 3.58 & 14.39 & 68.00 & 8.21 & 16.80 & 44.86 & 5.76 & 9.18 & 24.70 & 5.11 \\
\hline \multirow{3}{*}{$\begin{array}{c}\text { Shape and } \\
\text { size } \\
\text { adjustment } \\
\text { Surface } \\
\text { treatment }\end{array}$} & \multirow{2}{*}{$\begin{array}{l}\text { scraps } \\
\text { Stone sludge * } \\
\text { Solid stone } \\
\text { scraps }\end{array}$} & 1.91 & 6.00 & 0.71 & 0.08 & 0.30 & 0.03 & 1.54 & 5.00 & 0.88 & - & - & 0.00 & 1.49 & 4.00 & 0.83 \\
\hline & & 5.09 & 16.00 & 1.90 & 0.42 & 1.50 & 0.17 & 2.46 & 8.00 & 1.40 & - & - & 0.00 & 3.79 & 10.20 & 2.11 \\
\hline & \multirow{4}{*}{$\begin{array}{l}\text { Solid stone } \\
\text { scraps } \\
\text { Stone sludge * } \\
\text { Solid stone } \\
\text { scraps } \\
\text { Total volume }\end{array}$} & 2.80 & 11.40 & 1.04 & 0.70 & 11.00 & 0.29 & 1.10 & 10.60 & 0.63 & 2.10 & 5.61 & 0.72 & - & - & 0.00 \\
\hline \multirow{3}{*}{ Total } & & 29.36 & 233.10 & 10.96 & 19.83 & 192.72 & 8.10 & 44.15 & 204.20 & 25.19 & 60.90 & 162.60 & 20.88 & 13.00 & 35.50 & 7.23 \\
\hline & & 16.34 & 109.70 & 6.10 & 9.88 & 83.68 & 4.03 & 17.95 & 86.60 & 10.24 & 18.90 & 50.46 & 6.48 & 12.97 & 34.90 & 7.22 \\
\hline & & \multicolumn{3}{|c|}{ Processing plant 6} & \multicolumn{3}{|c|}{ Processing plant 7} & \multicolumn{3}{|c|}{ P2.10 290.80} & 79.80 & $\begin{array}{l}213.06 \\
\text { essing } p\end{array}$ & $9^{27.36}$ & 25.97 & $\begin{array}{l}70.40 \\
\text { essing } p\end{array}$ & $0^{14.45}$ \\
\hline \multirow{2}{*}{\multicolumn{2}{|c|}{$\begin{array}{l}\text { Quantity of rock material to be } \\
\text { processed, } \mathrm{m}^{3}\end{array}$}} & & 330.00 & & & 259.75 & & & 360.00 & & & 86.48 & & & 250.60 & \\
\hline & & Quant & e stone & $\begin{array}{l}\text { Loss of } \\
\text { stone } \\
\text { material }\end{array}$ & Quant & $e^{f \text { stone }}$ & $\begin{array}{c}\text { Loss of } \\
\text { stone } \\
\text { material }\end{array}$ & Quant & f stone & $\begin{array}{c}\text { Loss of } \\
\text { stone } \\
\text { material }\end{array}$ & Quant & $\mathrm{e}^{\mathrm{f} \text { stone }}$ & $\begin{array}{c}\text { Loss of } \\
\text { stone } \\
\text { material }\end{array}$ & Quant & $e^{f \text { stone }}$ & $\begin{array}{c}\text { Loss of } \\
\text { stone } \\
\text { material }\end{array}$ \\
\hline Pre- & Stone sludge * & $\begin{array}{c}\mathrm{m}^{3} \\
18.74\end{array}$ & $\begin{array}{c}\mathrm{Mg} \\
51.54\end{array}$ & $\begin{array}{c}\% \\
5.68\end{array}$ & $\begin{array}{c}\mathrm{m}^{3} \\
28.71\end{array}$ & $\begin{array}{c}\mathrm{Mg} \\
73.21\end{array}$ & $\begin{array}{c}\% \\
11.05\end{array}$ & $\mathrm{~m}^{3}$ & $\begin{array}{c}\mathrm{Mg} \\
112.02\end{array}$ & $\begin{array}{c}\% \\
11.53\end{array}$ & $\mathrm{~m}^{3}$ & $\begin{array}{c}\mathrm{Mg} \\
15.63\end{array}$ & $\begin{array}{l}\% \\
6.70\end{array}$ & $\begin{array}{c}\mathrm{m}^{3} \\
15.82\end{array}$ & $\underset{43.82}{\mathrm{Mg}}$ & $\begin{array}{l}\% \\
6.31\end{array}$ \\
\hline processing & $\begin{array}{l}\text { Solid stone } \\
\text { scraps }\end{array}$ & 18.70 & 51.43 & 5.67 & 16.34 & 41.67 & 6.29 & 21.44 & 57.89 & 5.96 & 3.10 & 8.37 & 3.58 & 8.50 & 23.55 & 3.39 \\
\hline Shape and & Stone sludge * & - & - & 0.00 & 2.12 & 5.41 & 0.82 & 5.67 & 15.31 & 1.58 & 2.70 & 7.29 & 3.12 & - & - & 0.00 \\
\hline $\begin{array}{c}\text { size } \\
\text { adjustment }\end{array}$ & $\begin{array}{l}\text { Solid stone } \\
\text { scraps }\end{array}$ & - & - & 0.00 & 5.40 & 13.77 & 2.08 & 7.60 & 20.52 & 2.11 & 3.44 & 9.29 & 3.98 & - & - & 0.00 \\
\hline Surface & Stone sludge * & - & - & 0.00 & 4.59 & 11.70 & 1.77 & 8.01 & 21.62 & 2.22 & 2.90 & 7.84 & 3.36 & 9.33 & 25.86 & 3.72 \\
\hline treatment & $\begin{array}{l}\text { Solid stone } \\
\text { scraps }\end{array}$ & - & - & 0.00 & - & - & 0.00 & 1.33 & 3.60 & 0.37 & - & - & 0.00 & 0.57 & 1.57 & 0.23 \\
\hline & Stone sludge * & 18.74 & 51.54 & 5.68 & 35.42 & 90.32 & 13.64 & 55.17 & 148.95 & 15.32 & 11.39 & 30.77 & 13.18 & 25.15 & 69.68 & 10.04 \\
\hline Total & $\begin{array}{l}\text { Solid stone } \\
\text { scraps }\end{array}$ & 18.70 & 51.43 & 5.67 & 21.74 & 55.44 & 8.37 & 30.37 & 82.01 & 8.44 & 6.54 & 17.66 & 7.56 & 9.07 & 25.11 & 3.62 \\
\hline & Total volume & 37.44 & 102.97 & 11.35 & 57.16 & 145.76 & 22.01 & 85.54 & 230.97 & 23.76 & 17.93 & 48.42 & 20.74 & 34.22 & 94.79 & 13.66 \\
\hline
\end{tabular}

* The volume of stone sludge was determined on the basis of the dried volume of hydrated grated stone material. 


\section{The Use of Waste from the Processing of Natural Stone}

Natural stone wastes from stonemasonry plants constitute a substantial part of all waste produced there and are a significant environmental problem, as they are not biodegradable [18]. The efficient production management in processing plants and the resulting rational stone waste management require the planning and designing of stone elements to be performed in such a way that the processed material is fully used as various stone products. It is also important to introduce technical solutions to reduce waste. Such an approach will affect a reduction in stone scrap production. Still, the generated stone scraps should continue to be properly processed. Although reusing waste is socially and environmentally important, it should also be economically profitable and technically feasible [16].

Generally, stone wastes from processing plants are environmentally neutral. However, according to Simsek et al. [19], Rizzo et al. [20], Nasserdine et al. [21], and Luodes et al. [22], they may also have a negative environmental impact. Therefore, the European Parliament and EC Directive 2008/98/EC of 19 November 2008 on waste [8] encourages other applications of stone wastes. Although stone wastes are generally stored in waste disposal facilities or in post-mining excavations, the literature on the subject mentions numerous proposals for their application (Table 4).

Table 4. Literature research on the possibilities of application of stone scraps.

\begin{tabular}{cccc}
\hline Application of Stone Scrap & Type of Stone Scrap & Material & References \\
\hline & powder/fine & granite & {$[23-33]$} \\
Building materials & aggregate & marble & {$[34-55]$} \\
(mortar/concrete/brick) & powder/fine & limestone & {$[56-61]$} \\
& aggregate & basalt & {$[62-65]$} \\
& coarse/fine aggregate & sandstone & {$[66-71]$} \\
& powder & mix/unidentified & {$[72-77]$} \\
& fine grained & granite & {$[78-80]$} \\
Caste/powder & marble & {$[81-85]$} \\
& powder & gneiss & {$[86-88]$} \\
Stabilised clay soil & & serpentinite & {$[89,90]$} \\
& powder & mix / unidentified & {$[91,92]$} \\
& & marble & {$[93]$} \\
& & limestone & {$[94-97]$} \\
Fertilisation & unidentified & mix $/$ unidentified & {$[98,99]$} \\
& powder & marble & {$[100]$} \\
& & basalt & {$[101,102]$} \\
& powder & gneiss & {$[103-106]$} \\
& & granite & {$[107]$} \\
Other applications & marble & {$[108-111]$}
\end{tabular}

In processing plants, various types and volumes of natural stone (e.g., granite, sandstone, limestone, marble) are often processed, which indicates the variety of stone waste and the different physical and chemical properties of these materials. The literature has repeatedly described both the possibilities of using stone scrap for the production of construction materials and their physicomechanical parameters. The largest number of studies showing the possibilities of using stone waste concerns granite and marble because of their widespread use in architecture and civil engineering. In addition, the largest number of studies were related to the use of stone powder. 
The analysis of the literature on the subject indicates the possibilities of using stone scrap in the construction industry, which is concerned with the selection of various mixtures with the use of stone waste (most often from the processing of granite and marble) to produce mortar, concrete, or bricks. These works reveal that the use of up to $35 \%$ of the volume of stone waste material for the production of Portland cement does not affect the quality parameters of this product [26]. Ghannam et al. [24] and Prošek et al. [46] indicate that using stone waste can increase the strength parameters of concrete. Additionally, the use of fine stone waste can be a good solution for the production of ceramic products. Luiz et al. [92] and Munir et al. [83,84] emphasise that the inclusion of $15 \%$ of ornamental stone waste in the production of ceramic products does not affect the properties of these products.

Saygili [93], Ibrahim et al. [94], Ogila [95], Pastor et al. [96], Sabat and Muni [97], Igwe and Adepehin [98], and Sivrikaya et al. [99] have shown that the application of stone scrap to stabilise clay soils is beneficial and, at the same time, improves geotechnical properties and reduces soil swelling. The use of fine rock material for fertiliser production, used in agriculture, as well as in the reclamation process, can have a positive impact on the growth of vegetation and improve soil properties [100,102-105].

Stone scraps can also be used to produce various composite materials. Karimi et al. [107] propose to use granite waste for the production of ecological stone composite based on acrylonitrile-butadiene-styrene (ABS), while Conde-Vázquez et al. [112] indicate the possibility of using sandstone waste for the production of artificial arenite using cement polymerisation. Kurańska et al. [113] point to the possibility of applying stone waste to the production of highly efficient porous polyurethane composites. Basalt waste can also be used as admixtures for gypsum composites [114]. The use of fine marble waste is possible to produce various other composite materials: geopolymer hybrid composite materials [108,111], composite materials with the structure of unsaturated polyester [110], or composite materials produced from waste PET [109].

Other applications of stone scrap do not represent a large-scale use. However, more research should be conducted into the possibilities of their usefulness. Alves et al. [115] point to the use of granite waste for rock wool production. Agrawal et al. [116], Marras, and Careddu [117] propose to use marble waste in the rubber industry, whereas Özkaya et al. [119] have conducted a study on the possibility of applying waste marble powder as an adhesive filler in the manufacturing of laminated veneer lumber (LVL). Navar et al. [118] have tested the possibility of using waste marble powder as a potential alternative to current commercial calcium carbonate sorbents for capturing $\mathrm{CO}_{2}$.

The reprocessing and reusing of stone scraps increase productivity and profitability while reducing the final production costs. In addition, it simultaneously limits the threat to the environment, reduces the number of non-biodegradable waste deposition sites, and offers alternative raw materials for various industrial activities. Table 5 shows general methods for using scraps generated in the processing of natural stone. 
Table 5. Different applications of scrap from dimension natural stone processing (own work based on Shamrai et al. [17] and Shirazi [120]).

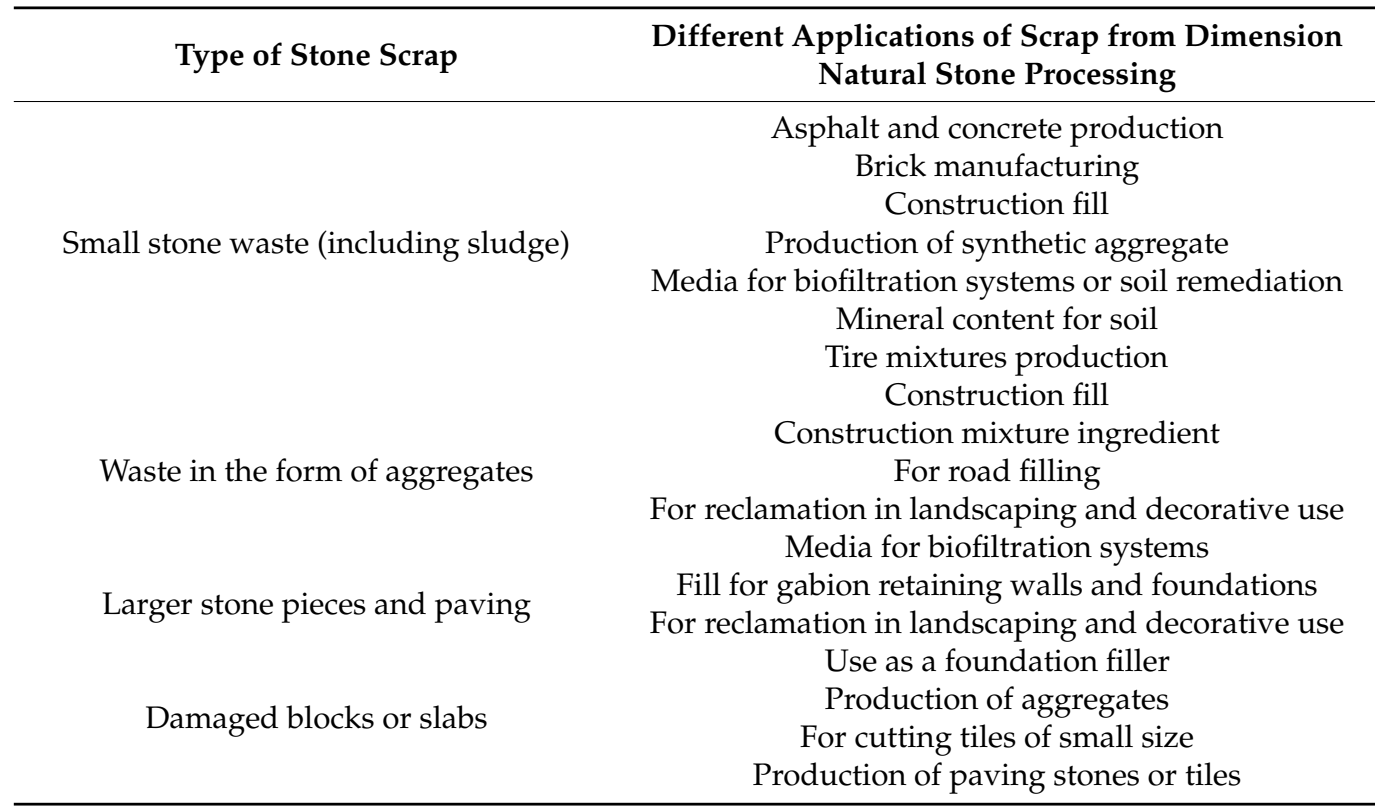

\section{Conclusions}

Production processes should be planned to maximise resource usage and environmental protection while balancing costs. One of the cost-intensive factors in the production process is energy. Energy efficiency is an important optimisation issue and should be understood as the amount of energy used to obtain a product. This issue has been addressed in many works on mining [121,122]. In the context of natural stone processing, this issue is also important because such processes require high energy input. The generated stone waste, which generally represents a loss of raw material, also affects the number of production costs. In addition, stone wastes produced in stone processing pose significant problems, which considerably affect the environment, as well as the production efficiency and profitability.

The produced stone waste, i.e., solid scraps and sludge, comprises $10-35 \%$ of the quantity of the processed natural stone, solid scraps accounting for almost threefold greater quantities. Most of this waste is generated in the first stage of stone processing. A reduction in the quantity of stone waste is possible if the production of stone elements is rationally planned in order to use the material with maximum efficiency and if companies decide to introduce modern machinery, which is now designed with a view to reducing stone waste. In addition to the need to reduce stone scrap, it is necessary to search for its usage. The use of scrap, once its potential has been discovered, is now considered to be an activity that can contribute to product diversification, reduce final costs, and provide alternative raw materials for a variety of industrial sectors [79].

Based on the analysis conducted in the article, the following two important research areas can be identified that should be developed with a view to waste reduction or reprocessing:

- Research efforts to find or improve a technology that reduces the volume of waste produced or the development of a waste-free technology;

- Research efforts to find possibilities of stone waste application.

Author Contributions: Conceptualization, P.S.; methodology, P.S.; software, P.S.; validation, P.S.; writing —original draft preparation, P.S.; writing — review and editing, P.S. All authors have read and agreed to the published version of the manuscript. 
Funding: This research was funded by the Polish Ministry of Education and Science Subsidy 2021 for the Department of Mining WUST, Grant Number 8211104160.

Institutional Review Board Statement: Not applicable.

Informed Consent Statement: Not applicable.

Data Availability Statement: Not Applicable.

Conflicts of Interest: The author declares no conflict of interest.

\section{References}

1. Strzałkowski, P. Requirements and test methods for selected natural stone products. Gór. Odkryw. 2018, 59, 34-40. (In Polish)

2. Careddu, N. Dimension stones in the circular economy world. Resour. Policy 2019, 60, 243-245. [CrossRef]

3. Careddu, N.; Dino, G.A. Reuse of residual sludge from stone processing: Differences and similarities between sludge coming from carbonate and silicate stones-Italian experiences. Environ. Earth Sci. 2016, 75, 1-9. [CrossRef]

4. Karaca, Z.; Pekin, A.; Deliormanl1, A.H.; Deliormanli, A.H. Classification of dimension stone wastes. Environ. Sci. Pollut. Res. 2012, 19, 2354-2362. [CrossRef]

5. Kaźmierczak, U.; Blachowski, J.; Górniak-Zimroz, J.; Wirth, H. Quantitative and Qualitative Research on the Waste from the Mining of Rock Raw Materials in Lower Silesia. Minerals 2018, 8, 375. [CrossRef]

6. Mosaferi, M.; Dianat, I.; Khatibi, M.S.; Mansour, S.N.; Fahiminia, M.; Hashemi, A.A. Review of environmental aspects and waste management of stone cutting and fabrication industries. J. Mater. Cycles Waste Manag. 2014, 16, 721-730. [CrossRef]

7. Yurdakul, M. Natural stone waste generation from the perspective of natural stone processing plants: An industrial-scale case study in the province of Bilecik, Turkey. J. Clean. Prod. 2020, 276, 123339. [CrossRef]

8. Directive 2008/98/EC of the European Parliament and of the Council of 19 November 2008 on Waste and Repealing Certain Directives, 2008/98/EC; EC: Brussels, Belgium, 2008.

9. Kaźmierczak, U.; Blachowski, J.; Górniak-Zimroz, J. Multi-Criteria Analysis of Potential Applications of Waste from Rock Minerals Mining. Appl. Sci. 2019, 9, 441. [CrossRef]

10. Tayebi-Khorami, M.; Edraki, M.; Corder, G.; Golev, A. Re-Thinking Mining Waste through an Integrative Approach Led by Circular Economy Aspirations. Minerals 2019, 9, 286. [CrossRef]

11. Woźniak, J.; Pactwa, K. Overview of Polish Mining Wastes with Circular Economy Model and Its Comparison with Other Wastes. Sustainbility 2018, 10, 3994. [CrossRef]

12. Yilmaz, E. Advances in reducing large volumes of environmentally harmful mine waste rocks and tailings. Gospod. Surowcami Miner.-Miner. Resour. Manag. 2011, 27, 89-112.

13. Lèbre, É.; Corder, G.; Golev, A. The Role of the Mining Industry in a Circular Economy: A Framework for Resource Management at the Mine Site Level. J. Ind. Ecol. 2017, 21, 662-672. [CrossRef]

14. Commission Decision of 18 December 2014 Amending Decision 2000/532/EC on the List of Waste Pursuant to Directive 2008/98/EC of the European Parliament and of the Council, 2014/955/UE; EC: Brussels, Belgium, 2014.

15. Singh, S.; Nagar, R.; Agrawal, V. Performance of granite cutting waste concrete under adverse exposure conditions. J. Clean. Prod. 2016, 127, 172-182. [CrossRef]

16. Mitchell, C.; Harrison, D.; Robinson, H.; Ghazireh, N. Minerals from Waste: Recent BGS and Tarmac experience in finding uses for mine and quarry waste. Miner. Eng. 2004, 17, 279-284. [CrossRef]

17. Shamrai, V.I.; Korobiichuk, V.V.; Sobolevskyi, R.V. Management of waste of stone processing in the framework of Euro integration of Ukraine. J. Zhytomyr State Technol. Univ. Ser. Eng. 2017, 1, 234-239. [CrossRef]

18. Lakhani, R.; Kumar, R.; Tomar, P. Utilization of Stone Waste in the Development of Value Added Products: A State of the Art Review. J. Eng. Sci. Technol. Rev. 2014, 7, 180-187. [CrossRef]

19. Simsek, C.; Karaca, Z.; Gemici, U.; Gunduz, O. The assessment of the impacts of a marble waste site on the water and sedi-ment quality in a river system. Fresenius Environ. Bull. 2005, 14, 1013-1023.

20. Rizzo, G.; D'Agostino, F.; Ercoli, L. Problems of soil and groundwater pollution in the disposal of "marble" slurries in NW Sicily. Environ. Earth Sci. 2008, 55, 929-935. [CrossRef]

21. Nasserdine, K.; Mimi, Z.; Bevan, B.; Elian, B. Environmental management of the stone cutting industry. J. Environ. Manag. 2009, 90, 466-470. [CrossRef] [PubMed]

22. Luodes, H.; Kauppila, P.M.; Luodes, N.; Aatos, S.; Kallioinen, J.; Luukkanen, S.; Aalto, J. Characteristics and the environmental acceptability of the natural stone quarrying waste rocks. Bull. Int. Assoc. Eng. Geol. 2012, 71, 257-261. [CrossRef]

23. Da Silva, J.L.; Campos, D.B.D.C.; Lordsleem, A.C.; Povoas, Y.V. Influence of the partial substitution of fine aggregate by granite powder in mortar on the process of natural carbonation. Waste Manag. Res. 2020, 38, 254-262. [CrossRef] [PubMed]

24. Ghannam, S.; Najm, H.; Vasconez, R. Experimental study of concrete made with granite and iron powders as partial replacement of sand. Sustain. Mater. Technol. 2016, 9, 1-9. [CrossRef]

25. Gupta, L.K.; Vyas, A.K. Impact on mechanical properties of cement sand mortar containing waste granite powder. Constr. Build. Mater. 2018, 191, 155-164. [CrossRef] 
26. Hussain, S.A.; Shirisha, P.; Kumar, T.; Krishna, S.V.; Satyanarayana, S.V. The Use of Granite Industry Waste as a Cement Substitute. Int. J. Eng. Res. Technol. 2013, 2, 894-898.

27. Li, L.; Wang, Y.; Tan, Y.; Kwan, A. Adding granite dust as paste replacement to improve durability and dimensional stability of mortar. Powder Technol. 2018, 333, 269-276. [CrossRef]

28. Lokeshwari, M.; Jagadish, K. Eco-friendly Use of Granite Fines Waste in Building Blocks. Procedia Environ. Sci. 2016, 35, 618-623. [CrossRef]

29. Boadella, Í.L.; Gayarre, F.L.; González, J.S.; Gómez-Soberón, J.M.; Pérez, C.L.-C.; López, M.S.; De Brito, J. The Influence of Granite Cutting Waste on the Properties of Ultra-High Performance Concrete. Materials 2019, 12, 634. [CrossRef]

30. Ramos, T.; Matos, A.M.; Schmidt, B.; Rio, J.; Sousa-Coutinho, J. Granitic quarry sludge waste in mortar: Effect on strength and durability. Constr. Build. Mater. 2013, 47, 1001-1009. [CrossRef]

31. Shamsabadi, E.A.; Ghalehnovi, M.; De Brito, J.; Khodabakhshian, A. Performance of Concrete with Waste Granite Powder: The Effect of Superplasticizers. Appl. Sci. 2018, 8, 1808. [CrossRef]

32. Singh, S.; Nagar, R.; Agrawal, V.; Rana, A.; Tiwari, A. Sustainable utilization of granite cutting waste in high strength concrete. J. Clean. Prod. 2016, 116, 223-235. [CrossRef]

33. Vijayalakshmi, M.; Sekar, A.; Sivabharathy, M.; Prabhu, G.G. Utilization of Granite Powder Waste in Concrete Production. Defect Diffus. Forum 2012, 330, 49-61. [CrossRef]

34. Alyamaç, K.E.; Ghafari, E.; Ince, R. Development of eco-efficient self-compacting concrete with waste marble powder using the response surface method. J. Clean. Prod. 2017, 144, 192-202. [CrossRef]

35. Alyamaç, K.E.; Ince, R. A preliminary concrete mix design for SCC with marble powders. Constr. Build. Mater. 2009, 23, 1201-1210. [CrossRef]

36. Bilgin, N.; Yeprem, H.; Arslan, S.; Bilgin, A.; Günay, E.; Marşoglu, M. Use of waste marble powder in brick industry. Constr. Build. Mater. 2012, 29, 449-457. [CrossRef]

37. Corinaldesi, V.; Moriconi, G.; Naik, T.R. Characterization of marble powder for its use in mortar and concrete. Constr. Build. Mater. 2010, 24, 113-117. [CrossRef]

38. Eliche-Quesada, D.; Iglesias, F.J.; Pérez-Villarejo, L.; Iglesias-Godino, F. Recycling of sawdust, spent earth from oil filtration, compost and marble residues for brick manufacturing. Constr. Build. Mater. 2012, 34, 275-284. [CrossRef]

39. Grilo, M.J.; Pereira, J.; Costa, C. Waste Marble Dust Blended Cement. Mater. Sci. Forum 2012, 730-732, 671-676. [CrossRef]

40. Kabeer, K.S.A.; Vyas, A.K. Utilization of marble powder as fine aggregate in mortar mixes. Constr. Build. Mater. 2018, 165, 321-332. [CrossRef]

41. Khyaliya, R.K.; Kabeer, K.S.A.; Vyas, A.K. Evaluation of strength and durability of lean mortar mixes containing marble waste. Constr. Build. Mater. 2017, 147, 598-607. [CrossRef]

42. Kore, S.D.; Vyas, A.K.; Syed, A.K.K.I. A brief review on sustainable utilisation of marble waste in concrete. Int. J. Sustain. Eng. 2020, 13, 264-279. [CrossRef]

43. Li, L.; Huang, Z.; Tan, Y.; Kwan, A.; Chen, H. Recycling of marble dust as paste replacement for improving strength, microstructure and eco-friendliness of mortar. J. Clean. Prod. 2019, 210, 55-65. [CrossRef]

44. Li, L.; Huang, Z.; Tan, Y.; Kwan, A.; Liu, F. Use of marble dust as paste replacement for recycling waste and improving durability and dimensional stability of mortar. Constr. Build. Mater. 2018, 166, 423-432. [CrossRef]

45. Mashaly, O.; El-Kaliouby, B.A.; Shalaby, B.; El-Gohary, A.; Rashwan, M. Effects of marble sludge incorporation on the properties of cement composites and concrete paving blocks. J. Clean. Prod. 2016, 112, 731-741. [CrossRef]

46. Prošek, Z.; Nežerka, V.; Tesárek, P. Enhancing cementitious pastes with waste marble sludge. Constr. Build. Mater. 2020, 255, 119372. [CrossRef]

47. Prošek, Z.; Trejbal, J.; Topič, J.; Plachý, T.; Tesárek, P. Utilization of the waste from the marble industry for application in transport infrastructure: Mechanical properties of cement pastes. IOP Conf. Ser. Mater. Sci. Eng. 2017, 236, 012092. [CrossRef]

48. Rodrigues, R.; de Brito, J.; Sardinha, M. Mechanical properties of structural concrete containing very fine aggregates from marble cutting sludge. Constr. Build. Mater. 2015, 77, 349-356. [CrossRef]

49. Seghir, N.T.; Mellas, M.; Sadowski, Ł.; Krolicka, A.; Żak, A.; Ostrowski, K. The Utilization of Waste Marble Dust as a Cement Replacement in Air-Cured Mortar. Sustainbility 2019, 11, 2215. [CrossRef]

50. Seghir, N.T.; Mellas, M.; Sadowski, Ł.; Żak, A. Effects of marble powder on the properties of the air-cured blended cement paste. J. Clean. Prod. 2018, 183, 858-868. [CrossRef]

51. Siddique, Z.; Bhargava, R.; Ansari, M.; Khan, W. Experimental study for the utilization of marble powder and in construction industry. In Proceedings of the International Conference on Sustainable Materials and Structures for Civil Infrastructures (SMSCI2019); AIP Publishing: Melville, NY, USA, 2019; Volume 2158, p. 020025.

52. Tunc, E.T. Recycling of marble waste: A review based on strength of concrete containing marble waste. J. Environ. Manag. 2019, 231, 86-97. [CrossRef]

53. Ulubeyli, G.C.; Bilir, T.; Artir, R. Durability Properties of Concrete Produced by Marble Waste as Aggregate or Mineral Additives. Procedia Eng. 2016, 161, 543-548. [CrossRef]

54. Vardhan, K.; Goyal, S.; Siddique, R.; Singh, M. Mechanical properties and microstructural analysis of cement mortar incorporating marble powder as partial replacement of cement. Constr. Build. Mater. 2015, 96, 615-621. [CrossRef] 
55. Vardhan, K.; Siddique, R.; Goyal, S. Influence of marble waste as partial replacement of fine aggregates on strength and drying shrinkage of concrete. Constr. Build. Mater. 2019, 228, 116730. [CrossRef]

56. Cavaleri, L.; Borg, R.P.; La Mantia, F.P.; Liguori, V. Quarry limestone dust as fine aggregate for concrete. IOP Conf. Ser. Mater. Sci. Eng. 2018, 442. [CrossRef]

57. Chouhan, H.S.; Kalla, P.; Nagar, R.; Gautam, P.K. Gainful utilization of dimensional limestone waste as fine aggregate in cement mortar mixes. Constr. Build. Mater. 2019, 221, 363-374. [CrossRef]

58. Chouhan, H.S.; Kalla, P.; Nagar, R.; Gautam, P.K.; Arora, A.N. Investigating use of dimensional limestone slurry waste as fine aggregate in mortar. Environ. Dev. Sustain. 2018, 22, 2223-2245. [CrossRef]

59. Kibriya, T.; Tahir, L. Sustainable Construction-High Performance Concrete Containing Limestone Dust as Filler. World J. Eng. Technol. 2017, 5, 404-411. [CrossRef]

60. Rana, A.; Kalla, P.; Csetenyi, L. Recycling of dimension limestone industry waste in concrete. Int. J. Min. Reclam. Environ. 2017, 31, 231-250. [CrossRef]

61. Turgut, P.; Algin, H.M. Limestone dust and wood sawdust as brick material. Build. Environ. 2007, 42, 3399-3403. [CrossRef]

62. Andrade, F.R.D.; Pecchio, M.; Bendoraitis, D.P.; Montanheiro, T.J.; Kihara, Y. Basalt mine-tailings as raw-materials for Portland clinker. Cerâmica 2010, 56, 39-43. [CrossRef]

63. Dobiszewska, M. Zastosowanie pyłu bazaltowego, jako substytutu piasku w zaprawie i betonie cementowym. Bud. Arch. 2016, 15, 075-085. [CrossRef]

64. Dobiszewska, M.; Barnes, R.W. Properties of Mortar Made with Basalt Powder as Sand Replacement. Mater. J. 2020, 117, 3-9. [CrossRef]

65. Dobiszewska, M.; Beycioğlu, A. Physical Properties and Microstructure of Concrete with Waste Basalt Powder Addition. Materials 2020, 13, 3503. [CrossRef] [PubMed]

66. Chandar, K.R.; Gayana, B.; Sainath, V. Experimental investigation for partial replacement of fine aggregates in concrete with sandstone. Adv. Concr. Constr. 2016, 4, 243-261. [CrossRef]

67. Gupta, R.C.; Basu, P.; Agrawal, S. Mechanical properties of self-compacting concrete containing sandstone slurry. IOP Conf. Ser. Mater. Sci. Eng. 2019, 689, 012002. [CrossRef]

68. Kumar, S.; Gupta, R.C.; Shrivastava, S. Long term studies on the utilisation of quartz sandstone wastes in cement concrete. J. Clean. Prod. 2017, 143, 634-642. [CrossRef]

69. Kumar, S.; Gupta, R.C.; Shrivastava, S.; Csetenyi, L.; Thomas, B.S. Preliminary study on the use of quartz sandstone as a partial replacement of coarse aggregate in concrete based on clay content, morphology and compressive strength of combined gradation. Constr. Build. Mater. 2016, 107, 103-108. [CrossRef]

70. Kumar, S.; Thomas, B.S.; Gupta, V.; Basu, P.; Shrivastava, S. Sandstone wastes as aggregate and its usefulness in cement concrete-A comprehensive review. Renew. Sustain. Energy Rev. 2018, 81, 1147-1153. [CrossRef]

71. Singhal, A.; Goel, S.; Sengupta, D. Physicochemical and elemental analyses of sandstone quarrying wastes to assess their impact on soil properties. J. Environ. Manag. 2020, 271, 111011. [CrossRef] [PubMed]

72. Almada, B.S.; Melo, L.D.S.; Dutra, J.B.; Bubani, L.C.; Silva, G.J.B.; dos Santos, W.J.; Aguilar, M.T.P. Influence of the heterogeneity of waste from wet processing of ornamental stones on the performance of Portland cement composites. Constr. Build. Mater. 2020, 262, 120036. [CrossRef]

73. Amin, S.K.; Allam, M.E.; Garas, G.L.; Ezz, H. A study of the chemical effect of marble and granite slurry on green mortar compressive strength. Bull. Natl. Res. Cent. 2020, 44, 1-5. [CrossRef]

74. Bacarji, E.; Filho, R.T.; Koenders, E.; Figueiredo, E.; Lopes, J. Sustainability perspective of marble and granite residues as concrete fillers. Constr. Build. Mater. 2013, 45, 1-10. [CrossRef]

75. Chouhan, H.S.; Kalla, P.; Nagar, R.; Gautam, P.K. Influence of dimensional stone waste on mechanical and durability properties of mortar: A review. Constr. Build. Mater. 2019, 227, 116662. [CrossRef]

76. Galetakis, M.; Soultana, A. A review on the utilisation of quarry and ornamental stone industry fine by-products in the construction sector. Constr. Build. Mater. 2016, 102, 769-781. [CrossRef]

77. Rana, A.; Kalla, P.; Verma, H.; Mohnot, J. Recycling of dimensional stone waste in concrete: A review. J. Clean. Prod. 2016, 135, 312-331. [CrossRef]

78. Araújo, A.J.M.; O Sousa, A.R.; Macedo, D.A.; Dutra, R.P.S.; Campos, L.F.A.; De Sousa, A.R.O. Effects of granite waste addition on the technological properties of industrial silicate based-ceramics. Mater. Res. Express 2019, 6, 125205. [CrossRef]

79. Menezes, R.R.; Ferreira, H.S.; Neves, G.A.; Lira, H. Use of granite sawing wastes in the production of ceramic bricks and tiles. J. Eur. Ceram. Soc. 2005, 25, 1149-1158. [CrossRef]

80. Panna, W.; Wyszomirski, P.; Gajek, M. Characteristics of the fine-grained fractions of the crushed Strzegom granites as possi-ble materials in manufacture of ceramic tiles. Gospod. Surowcami Miner.-Miner. Resour. Manag. 2015, 31, 59-75. [CrossRef]

81. El-Mahllawy, M.S.; Kandeel, A.M.; Latif, M.L.A.; El Nagar, A.M. The Feasibility of Using Marble Cutting Waste in a Sustainable Building Clay Industry. Recycling 2018, 3, 39.

82. Montero, M.A.; Jordán, M.; Crespo, M.S.H.; Sanfeliu, T. The use of sewage sludge and marble residues in the manufacture of ceramic tile bodies. Appl. Clay Sci. 2009, 46, 404-408. [CrossRef]

83. Munir, M.J.; Abbas, S.; Nehdi, M.L.; Kazmi, S.M.S.; Khitab, A. Development of Eco-Friendly Fired Clay Bricks Incorporating Recycled Marble Powder. J. Mater. Civ. Eng. 2018, 30, 04018069. [CrossRef] 
84. Munir, M.J.; Kazmi, S.M.S.; Wu, Y.-F.; Hanif, A.; Khan, M.U.A. Thermally efficient fired clay bricks incorporating waste marble sludge: An industrial-scale study. J. Clean. Prod. 2018, 174, 1122-1135. [CrossRef]

85. Yeşilay, S.; Çak1, M.; Ergun, H. Usage of marble wastes in traditional artistic stoneware clay body. Ceram. Int. 2017, 43, 8912-8921. [CrossRef]

86. El-Mehalawy, N.; El-Omla, M.; Naga, S.M. Stoneware Tiles Based on Gneiss Rocks. Interceram-Int. Ceram. Rev. 2018, 67, 26-33. [CrossRef]

87. Moreira, J.; Manhães, J.; Holanda, J. Processing of red ceramic using ornamental rock powder waste. J. Mater. Process. Technol. 2008, 196, 88-93. [CrossRef]

88. Souza, A.; Pinheiro, B.; Holanda, J. Recycling of gneiss rock waste in the manufacture of vitrified floor tiles. J. Environ. Manag. 2010, 91, 685-689. [CrossRef] [PubMed]

89. Cavallo, A. Serpentinitic waste materials from the dimension stone industry: Characterization, possible reuses and critical issues. Resour. Policy 2018, 59, 17-23. [CrossRef]

90. Díaz, L.; Torrecillas, R. Porcelain stoneware obtained from the residual muds of serpentinite raw materials. J. Eur. Ceram. Soc. 2007, 27, 2341-2345. [CrossRef]

91. Amaral, L.F.; de Carvalho, J.P.R.G.; da Silva, B.M.; Delaqua, G.C.G.; Monteiro, S.N.; Vieira, C.M.F. Development of ceramic paver with ornamental rock waste. J. Mater. Res. Technol. 2019, 8, 599-608. [CrossRef]

92. Luiz, N.F.; Cecchin, D.; Azevedo, A.R.G.; Alexandre, J.; Marvila, M.T.; Da Silva, F.C.; Paes, A.L.C.; Pinheiro, V.D.; Do Car-mo, D.F.; Ferraz, P.F.P.; et al. Characterization of materials used in the manufacture of ceramic tile with incorporation of or-namental rock waste. Agron. Res. 2020, 18, 904-914. [CrossRef]

93. Saygili, A. Use of Waste Marble Dust for Stabilization of Clayey Soil. Mater. Sci. 2015, 21, 601-606. [CrossRef]

94. Ibrahim, H.H.; Alshkane, Y.M.; Mawlood, Y.I.; Noori, K.M.G.; Hasan, A.M. Improving the geotechnical properties of high expansive clay using limestone powder. Innov. Infrastruct. Solutions 2020, 5, 1-11. [CrossRef]

95. Ogila, W.A.M. The impact of natural ornamental limestone dust on swelling characteristics of high expansive soils. Environ. Earth Sci. 2016, 75, 1493. [CrossRef]

96. Pastor, J.L.; Tomás, R.; Cano, M.; Riquelme, A.; Gutiérrez, E. Evaluation of the Improvement Effect of Limestone Powder Waste in the Stabilization of Swelling Clayey Soil. Sustainbility 2019, 11, 679. [CrossRef]

97. Sabat, A.K.; Muni, P.K. Effects of limestone dust on geotechnical properties of an expansive soil. Int. J. Appl. Eng. Res. 2015, 10, 37724-37730.

98. Igwe, O.; Adepehin, E.J. Alternative Approach to Clay Stabilization Using Granite and Dolerite Dusts. Geotech. Geol. Eng. 2017, 35, 1657-1664. [CrossRef]

99. Sivrikaya, O.; Kıyıldı, K.R.; Karaca, Z. Recycling waste from natural stone processing plants to stabilise clayey soil. Environ. Earth Sci. 2014, 71, 4397-4407. [CrossRef]

100. Tozsin, G.; Arol, A.I.; Oztas, T.; Kalkan, E. Using marble wastes as a soil amendment for acidic soil neutralization. J. Environ. Manag. 2014, 133, 374-377. [CrossRef]

101. Artico, M.; Firpo, B.A.; Artico, L.L.; Tubino, R.M.C. Integrated use of sewage sludge and basalt mine waste as soil substitute for environmental restoration. REM-Int. Eng. J. 2020, 73, 225-232. [CrossRef]

102. Zagożdżon, P.P. Basalt Powder in Agricultural Use. Min. Sci. 2008, 10, 133-142. (In Polish)

103. De Souza, M.E.P.; Cardoso, I.M.; De Carvalho, A.M.X.; Lopes, A.P.; Jucksch, I. Gneiss and steatite vermicomposted with organic residues: Release of nutrients and heavy metals. Int. J. Recycl. Org. Waste Agric. 2019, 8, 233-240. [CrossRef]

104. De Souza, M.E.P.; Cardoso, I.M.; De Carvalho, A.M.X.; Lopes, A.P.; Jucksch, I.; Janssen, A. Rock Powder Can Improve Vermicompost Chemical Properties and Plant Nutrition: An On-farm Experiment. Commun. Soil Sci. Plant Anal. 2018, 49, 1-12. [CrossRef]

105. Dino, G.A.; Passarella, I.; Ajmone-Marsan, F. Quarry rehabilitation employing treated residual sludge from dimension stone working plant. Environ. Earth Sci. 2014, 73, 7157-7164. [CrossRef]

106. Kufka, D.; Cichoń, T.; Pomorski, A. Use of Gneiss Waste for Cultivation of Maize under Natural Sunflow Conditions. Gór. Odkryw. 2019, 60, 25-29. (In Polish)

107. Karimi, D.; Crawford, B.; Milani, A.S. Manufacturing process and mechanical properties of a novel acrylonitrile butadiene styrene-based composite, with recycled natural granite micro-particles. Manuf. Lett. 2020, 23, 79-84. [CrossRef]

108. Bakshi, P.; Pappu, A.; Patidar, R.; Gupta, M.K.; Thakur, V.K. Transforming Marble Waste into High-Performance, Water-Resistant, and Thermally Insulative Hybrid Polymer Composites for Environmental Sustainability. Polymers 2020, 12, 1781. [CrossRef] [PubMed]

109. Çınar, M.E.; Kar, F. Characterization of composite produced from waste PET and marble dust. Constr. Build. Mater. 2018, 163, 734-741. [CrossRef]

110. Doan, T.T.L.; Brodowsky, H.M.; Gohs, U.; Mäder, E. Re-Use of Marble Stone Powders in Producing Unsaturated Polyester Composites. Adv. Eng. Mater. 2018, 20, 1701061. [CrossRef]

111. Thakur, A.K.; Pappu, A.; Thakur, V.K. Synthesis and characterization of new class of geopolymer hybrid composite materials from industrial wastes. J. Clean. Prod. 2019, 230, 11-20. [CrossRef]

112. Conde-Vázquez, C.; Martín, O.D.M.-S.; García-Herbosa, G. Artificial arenite from wastes of natural sandstone industry. Mater. Constr. 2019, 69, 178. [CrossRef] 
113. Kurańska, M.; Barczewski, M.; Uram, K.; Lewandowski, K.; Prociak, A.; Michałowski, S. Basalt waste management in the production of highly effective porous polyurethane composites for thermal insulating applications. Polym. Test. 2019, 76, 90-100. [CrossRef]

114. Petropavlovskaya, V.B.; Novichenkova, T.B.; Zavadko, M.Y.; Petropavlovskii, K.S. On the potential use of basalt waste as mineral fillers. IOP Conf. Ser. Mater. Sci. Eng. 2020, 791, 012070. [CrossRef]

115. Alves, J.O.; Espinosa, D.C.R.; Tenório, J.A.S. Recovery of Steelmaking Slag and Granite Waste in the Production of Rock Wool. Mater. Res. 2015, 18, 204-211. [CrossRef]

116. Agrawal, S.; Mandot, S.; Bandyopadhyay, S.; Mukhopadhyay, R.; Dasgupta, M.; De, P.; Deuri, A. Use of Marble Waste in Rubber Industry: Part I (in NR Compound). Prog. Rubber Plast. Recycl. Technol. 2004, 20, 229-246. [CrossRef]

117. Marras, G.; Careddu, N. Sustainable reuse of marble sludge in tyre mixtures. Resour. Policy 2018, 59, 77-84. [CrossRef]

118. Nawar, A.; Ghaedi, H.; Ali, M.; Zhao, M.; Iqbal, N.; Khan, R. Recycling waste-derived marble powder for $\mathrm{CO}_{2}$ capture. Process. Saf. Environ. Prot. 2019, 132, 214-225. [CrossRef]

119. Özkaya, K.; Ayrilmis, N.; Özdemir, S. Potential use of waste marble powder as adhesive filler in the manufacture of laminated veneer lumber. BioRes 2015, 10, 1686-1695. [CrossRef]

120. Shirazi, E.K. Reusing of stone waste in various industrial activities. In Proceedings of the 2nd International Conference on Environmental Science and Development, Singapore, 26-28 February 2011; Volume 4, pp. 217-219.

121. Kawalec, W.; Suchorab, N.; Konieczna-Fuławka, M.; Król, R. Specific Energy Consumption of a Belt Conveyor System in a Continuous Surface Mine. Energies 2020, 13, 5214. [CrossRef]

122. Bortnowski, P.; Gładysiewicz, L.; Król, R.; Ozdoba, M. Energy Efficiency Analysis of Copper Ore Ball Mill Drive Systems. Energies 2021, 14, 1786. [CrossRef] 